Original Article

\title{
Spiritual Dimension in Art Therapy
}

\author{
Beyza Kırca ${ }^{1 \odot}$ \\ Istanbul Sabahattin Zaim University
}

\begin{abstract}
Spiritually-oriented art therapy interventions are based on a holistic, therapeutic approach that aims to enable people who are in fragmented states to achieve integrity, unity, harmony, and balance by taking all the mental, emotional, physical, and spiritual dimensions of human nature into account using the medium of art and its creative processes. Art is considered intrinsically spiritual by many artists and art therapists, and the history of art and its relationship to treatment is as old as human history; however, open consideration of the spiritual dimension in therapeutic settings, particularly in art therapy interventions, is relatively new. Reviewing the emergence of spiritually-oriented art therapy interventions and their mechanisms of change is considered useful for seeing how they enable holistic transformation. These mechanisms have been determined as self-realization and understanding, transcendence, meaning-making and searching for a purpose, and achieving integrity through the holistic wellbeing approach.
\end{abstract}

Keywords

Art therapy $\bullet$ Spirituality $\bullet$ Therapeutic $\bullet$ factors

\section{Sanat Terapisinde Manevi Boyut \\ Öz}

Manevi yönelimli sanat terapisi müdahaleleri, sanat ve yaratıcı süreç aracılığıyla, insan doğasının zihinsel, duygusal, fiziksel ve ruhsal olmak üzere tüm boyutlarını göz önünde bulundurarak parçalanmış hallerdeki insanların, bütünlüğe, birliğe, uyuma ve dengeye ulaşmasını amaçlayan bütünsel bir terapötik yaklaşıma dayanmaktadır. Sanat, birçok sanatçı ve sanat terapisti tarafından özünde manevi olarak kabul edilir ve sanat ile tedavi ilişkisinin tarihi, insanlık tarihi kadar eskidir; yine de terapötik ortamlarda, özellikle sanat terapisi müdahalelerinde manevi boyutu açıça dikkate almak nispeten yenidir. Bütüncül bir dönüşümü nasıl sağladıklarını görmek için manevi yönelimli sanat terapisi müdahalelerinin ortaya çıkışını ve değişim mekanizmalarını gözden geçirmenin yararlı olacağı düşünülmüştür. Bu mekanizmalar, kendini gerçekleştirme ve anlama, aşkınlık, anlamlandırma ve amaç arayışı, bütünlüğe ulaşma yoluyla bütünsel iyi oluş yaklaşımı olarak belirlenmiştir.

\section{Anahtar kelimeler \\ Sanat terapisi $\bullet$ maneviyat $\bullet$ terapötik faktörler}

\footnotetext{
1 Correspondence to: Beyza Kırca, Istanbul Sabahattin Zaim University, Faculty of Education, Department of Guidance and Psychological Counselling, beyza.kirca@izu.edu.tr

Citation: Kırca, B. (2019). Spiritual dimension in art therapy. Spiritual Psychology and Counseling, 4, 257-274. http://dx.doi.org/10.37898/spc.2019.4.3.071
} 
The use of art as a way of healing people is as old as the history of humankind (Malchiodi, 2006). Art's power as a means of communication has been recognized long before the emergence of its use as a therapeutic technique in professional practices (Junge \& Wadeson, 2006; McNiff, 1981). The first examples of art used as a treatment date back to the early and pre-Stone Age and are associated with shamanic cultures. In these early examples, the use of the imagination in the form of animal drawings found in the 30,000-year-old Chauvet-Pont-d'Arc cave, which have been assumed to be drawn for ritual purposes, is one striking example (McNiff, 1992). The experience of making art as a spiritual activity has taken place at various times and in various cultures; as Rudolf Steiner (1964, p. 17) stated, "In all ages the human souls in which the artistic element flourished have had a definite relation to the spiritual world. It was out of a spirit-attuned state that the artistic urge proceeded." Tibetan Lamaist monks' (Gordon, 1973, as cited in Soden 1998), Native Americans' (Cajete, 1994), and Islamic Sufis' (Tenik, 2014) engagement in art work as a spiritual activity can be added as other examples.

In addition to its deep-rooted history, art is a universal language with respect to the view that man thinks through images, and language is not a substitute for this process (Sutherland, 1995). The healing power of art is hidden in its abilities to eliminate the limits of introspection through verbal access and oral defenses, to communicate directly with emotions beyond the state of consciousness, and to address the human being as a whole (Czamanski-Cohen \& Weihs, 2016; Hartley, 2012; Kapitan, 2014). Along with the power of art therapy in removing the limits of oral communication, art offers opportunities to remove blockages and reframe old behaviors and thoughts with the help of creative processes (Wallace, 2015). As stated by the American Art Therapy Association (2017), "Through integrative methods, art therapy engages the mind, body, and spirit in ways that are distinct from verbal articulation alone. Kinesthetic, sensory, perceptual, and symbolic opportunities invite alternative modes of receptive and expressive communication, which can circumvent the limitations of language." Additionally, art can be used as a support for improving people's strengths, their growth, and improvement by providing access to individuals' internal resources; increasing their sense of self, awareness, and accomplishment; and enabling psychosocialdevelopmental transformation (Olivera, Toler, \& Trevithick, 2011).

The philosophical foundations of art therapy are based on holism; according to this view, the importance given in today's culture to the mechanistic approach rather than the creative process underlying art creates a kind of imbalance in people that then leads to physical and mental illnesses. This mechanistic approach, particularly common in Western society, involves compartmentalizing information. Its practice of understanding human beings involves separating an individual's sensations, feelings, thoughts, and deep desires of the soul into segments. As a result, a loss of unity in 
exploring complex dynamics has emerged as the primary basis of pathologies (Doyle, 2001; Kliewer \& Saultz, 2006; Sutherland, 1995). Beck (1989) emphasized the importance from a Zen philosophical perspective of becoming aware of everything that enters one's life internally or externally for achieving transformation and stated, "A mind that is not aware will produce illness." While very powerful statements in terms of causality, they have lain the foundation for the philosophy of art therapy and mechanisms of change rather than for asserting scientific results.

Despite the old relationship between art and treatment, art therapy is a young discipline (Franklin, Farrelly-Hansen, Marek, Swan-Foster, \& Wallingford, 2011) with the consideration and open incorporation of the spiritual dimension in art therapy as a more recent effort. Art's intertwined relationship with spirituality makes it possible to practice art therapy on the basis of very different and diverse approaches and beliefs. Art therapy interventions differ greatly in terms of aim, scope, context, and technique (Blomdahl, Gunnarsson, Guregard, \& Björklund, 2013; Geue et al., 2010), nor does the situation appear to differ for spiritually-oriented art therapy interventions as well. Making an overview of the spiritually-oriented art therapy interventions and therapeutic factors they share is considered useful for seeing how they make transformation and healing possible by integrating the spiritual aspect into therapy. Using this aim, this article will present the origins of art therapy; what art therapy is; the emergence of spiritually-oriented art therapy interventions; the relationship among art, spirituality, and healing; and the mechanisms of change this relation enables.

\section{The Origins of Art Therapy}

Art therapy is a product of the intellectual and social climate of the 20th century (Junge \& Asawa, 1994). The post-industrial era is when art became accessible to a new segment in Western society. The emergence of art therapy has historically coincided with the transition period when the art industry was eager for production and art movements broke away from the classical and conservative, presented new ideas, and became accessible to the middle class (Hart, 1976, as cited in Hluska, 2016). In the period when art therapy was emerging as a profession, the concept of art was being widely discussed by many philosophers and educators such as Dewey and Langer. Margaret Naumburg, Edith Kramer, Hanna Kwiatkowska, and Elinor Ulman are four important writers who contributed to the field's development (Vick, 2003). Margaret Naumburg, known as the Mother of Art Therapy, is especially regarded as the primary founder of American art therapy (Junge \& Asawa, 1994). Cane (1951/1983), Kellogg (1969), Lowenfeld (1987), and Uhlin (1972/1984) are also some names that have emphasized the importance of art in child development (cited in Vick, 2003). 
Art therapy began to be used in the clinical setting back in the 1930s with the work of Mary Huntoon. These first works began with a program supported by the American government. Huntoon (1949) was the first to make explanations about the healing mechanisms of art on war veterans (as cited in Wix, 2000).

Marty Huntoon's efforts to heal the psychological damages of war in the 1930s pioneered the attempts to practice art therapy as a profession. An important advancement in the field occurred in 1969: the establishment of the American Art Therapy Association. Looking at the general course, art therapy has emerged and developed over the last 70 years. Previously, the focus was mainly on functions such as evaluating and relieving those with severe mental disorders. Just like the course of the science of psychology, art therapy was primarily influenced by the psychodynamic approach, and art therapist Margaret Naumburg is the name that symbolizes the crossover between art therapy and the psychodynamic approach (Vick, 2003). Later on, this would be characterized by the Jungian, behavioral, cognitive, and humanistic movements (Allen, 2013; Vick, 2003). Although the transpersonal dimension had not been mentioned much until the 2000s, it has begun to be used with an eclectic approach along with the developments in this field, especially in wellbeing based therapies (Allen, 2013; Franklin, Farrelly-Hansen, Marek, Swan-Foster, \& Wallingford, 2011).

\section{What is Art Therapy?}

Combining the fields of art, psychology, and therapy, art therapy is a discipline within the scope of human services that enables people to discover their problems and potentials through non-verbal means (Olivera, Toler, \& Trevithick, 2011). The American Art Therapy Association (2017) defines art therapy as "an integrative mental health and human services profession that enriches the lives of individuals, families, and communities through active art-making, creative process, applied psychological theory, and human experience within a psychotherapeutic relationship." Art therapy uses creativity to deal with individuals' emotional, psychological, and physical problems. It enables clients to accept and establish a deep relationship with themselves (Wallace, 2015) while offering a tangible object for self-reflection and understanding (Bell, 2011).

Art therapy provides benefits in the following processes (Olivera, Toler, \& Trevithick, 2011):

1. It provides information during evaluation and diagnosis.

2. It helps greatly while making decisions about treatment.

3. It allows one to access emotions and becomes a safe outlet for them. 
4. It provides direct access to conflicts, as clients have no commonly-used defenses in oral therapies.

5. It makes arriving at inner experiences metaphorically possible.

6. It offers the opportunity for catharsis and to orientate the drives toward something good.

7. It ensures an active and responsible role for the client in therapy.

Above all, art therapy can be applied to individuals of all ages and conditions, as well as to groups, families, and couples. In particular, people who are emotionally obstructed, who have a tendency to scrutinize with too much logic, who find it easier to express themselves with visual images, who experience deep emotions after producing art, who have pre-speech traumas, who have unresolved issues such as trauma or loss, or who have transformational challenges can appropriately be directed to art therapy (Monti et al., 2006; Olivera, Toler, \& Trevithick, 2011, p. 256). When considering that some clients drop out of treatment and others don't share a Western culture, some people can be assumed to need different kinds of interventions other than conventional ones (Sandell, 2003, as cited in Blomdahl, Gunnarsson, Guregard, \& Björklund, 2013; Geue et al., 2010; Johnson, 2013). Art therapy is seen used particularly in hospitals as a complementary therapy for people with serious illnesses such as cancer, AIDS, asthma, burns, chemical dependency, trauma, tuberculosis, psychosis, and other medical and rehabilitation needs, particularly those in palliative care (Malchiodi, 1999a, 1999b; Ponto et al., 2003; Collie, Bottorf, \& Long, 2006; Hartley, 2012; Van Lith, 2016; Vick, 2003).

\section{The Emergence of Spiritually-Oriented Art Therapy Interventions}

Science and religion have begun to speak with each other in today's Western world again after 200 years of resentment (Farrelly-Hansen, 2001; Koepfer, 2000). Since the 17 th century, an "unwritten contract of non-relationship between religion and science had existed, and the mention of spirituality was done at the expense of being alienated from some scientific camps (Horowitz-Darby, 1994). Although patients consider spirituality as an integral part of their recovery process (Koepfer, 2000) and many psychologists and psychiatrists have stated personally appreciating and giving importance to spirituality (Larson, 1998), for a long time spirituality and religion were ignored in the clinical and psychotherapeutic fields for the sake of being rational, objective, intellectual, reductive, and thus scientific (Dossey, 1997). Many professionals were afraid to include the spiritual element in the therapy environment (Koepfer, 2000), and this element was also largely overlooked in art therapy discussions about recovery (Van Lith, 2014). The reasons for this misgiving may be considered as the Freudian stance of considering religious and spiritual 
beliefs as neurotic and pathological (Ahlskog, 1990), the idea that science should be values-free, and the lack of clarity and debate about the definition and application of spirituality (Horowitz-Darby, 1994; Kubler-Ross, 1983). In spite of these influences from the past, spirituality has been considered and accepted as a matter of scientific importance and has begun being considered as an element of support for treatment in many medical fields (Kearney \& Mount, 2000; Koepfer, 2000; Swinton, 2001).

Not only did psychology and spirituality have a falling out during the industrial revolution and the social climate of that time; so also were art and spirituality alienated (Farrelly-Hansen, 2001). Rudolf Steiner (1964, p. 116) expressed this as: "Art, always a daughter of the divine, has become estranged from her parent. If it finds its way back to its origins and is again accepted by the divine, then it will become what it should within civilization, within worldwide culture: a boon for mankind."

In the last quarter of the 19th century, artists began to show a tendency towards reality beyond the material again. One of the most important artists in this field is Kandinsky, who presented art as a form of spiritual expression and tried to draw attention to the spiritual aspect of art. Although many artists have supported this trend, one can say it remained a downstream flow. While interest in spirituality had decreased before and during World Wars I and II, topics such as Jungian thought and the place of spirituality in art began being spoken openly among artists after the 1960s (Farrelly-Hansen, 2001). Carl Jung is seen by many as the pioneer of art therapy (Landgarten, 1981; Wadeson, 1980) and has also been described as "the earliest transpersonal art therapist" (Franklin, Farrelly-Hansen, Marek, SwanFoster, \& Wallingford, 2011). He is known for utilizing sand play and other freeform improvisational art, including dance and music, for the sake of releasing unconscious materials and resistance (Kossak, 2009). The process of individuation is a central theme in Jung's theory (LaPointe, 2009), which he basically explained as "to penetrate into the secret of personality" (Jung, 1961, p. 206). Jung emphasized the importance of the processes of exploring and integrating the spiritual dimensions for individuation, which could be achieved using the imagery (archetypal symbols) of dreams and art (Jung, 1961).

Some art therapists who had added a spiritual dimension to their art therapy interventions can be named here. Florance Cane (1951), sister to Margaret Naumburg's sister (Vick, 2003), was one of the pioneers who brought artistic exercises together with meditative awareness. Joan Kellogg (1976), another art therapist in the field, used mandala drawing activities as the subject of consciousness studies at the Institute of Maryland Psychiatry Research. Joseph Garai (1976), meanwhile, engaged in the re-identification of personality. He achieved this re-identification and transition to the transpersonal through the use of artistic imagery and mediation that emerged after 
internal discovery (Farrelly-Hansen 2001; Franklin, 2015, Franklin, Farrelly-Hansen, Marek, Swan-Foster, \& Wallingford, 2011).

Catherine Moon was one of the first to make a connection between art and worship in 1989 at a conference on art therapy. Roberta Shoemaker-Beal and Phoebe Dufrene (1991) were the organizers of the panel "My God Left Me? Spirituality, Wholeism, and the Transpersonal in Art Therapy" (as cited in Farrelly-Hansen, 2001; Franklin, Farrelly-Hansen, Marek, Swan-Foster, \& Wallingford, 2011). HorovitzDarby (1994) is another important name that had published the book Spiritual Art Therapy, developed art-based spirituality assessments, and established a clinical connection between art and spirituality. Farrelly-Hansen (2001) and McNiff (1992) emphasized spiritual and philosophical concepts over psychological theory (Vick, 2003). Franklin, Farrelly-Hansen, Marek, Swan-Foster, and Wallingford (2000) described a transpersonal approach to art therapy and initiated a graduate program at Naropa University that combined art therapy training with transpersonal counseling psychology.

\section{Art, Spirituality, and Healing}

This section will examine the relationships among art, spirituality, and healing and to this end will summarize the ideas of different art therapists with different spiritual orientations regarding the relationship between artistic practices and spirituality and the healing power of this association. The therapeutic factors in spiritually-oriented therapy interventions will be examined to see how these different practices make transformation and healing possible.

Spirituality comes from the Latin word spiritus, meaning breath, courage, strength, or spirit; in this sense spiritus is that which gives life (Spiritus, 2019). For this reason, spirituality exists within everything and is also intimate in the therapy session. Therefore, art is intrinsically spiritual, and spirituality is an indispensable element of psychotherapy and integration (Farrelly-Hansen, 2001, Bell, 2011). Emphasizing spirituality as an inevitable dimension of psychotherapy seems plausible and also necessary, considering its religious connotations. While religious affiliation is subject to choice, spirituality is the fundamental aspect of a person that is universal across cultures and history (Cobb, 2001; Larson, Swyers, \& McCullough, 1997; Matthews \& Clark, 1999). It is a significant part of life that allows one to understand the self beyond the level of ego (Corrigan, McCorkle, Schell, \& Kidder, 2003). While some theorize spirituality as one of the various aspects of personhood (Rougemont, 1945, as cited in Kliewer \& Saultz, 2006) others consider spirituality as a core component and intersection point between all aspects of personhood (Tournier, 1964; Puchalski, 2012). 
Segregating spirituality from the core of human experience is impossible, particularly in the case of suffering (Bell, 2011). People who suffer from mental illness are observed having hard times in life and questioning themself and their life. This questioning brings about a reconsidering and revision of their sense of self and life. Afterwards comes rebuilding a sense of self, a process that enables recovery (Czamanski-Cohen \& Weihs, 2016; Yanos, Roe, \& Lysaker, 2010). This is a holistic transformation that requires taking all aspects of a person into account with spirituality being one of these (Cobb, 2001; Larson, Swyers, \& McCullough, 1997; Matthews \& Clark, 1999).

Therefore, by investigating the mechanisms of change, this section will discuss how art therapy interventions that consider the spiritual dimension enable these processes and holistic transformation. These mechanisms of change have been determined as self-realization and understanding, transcendence, meaning-making and search for a purpose, and achieving integrity through the holistic wellbeing approach.

\section{Self-Realization and Understanding}

Reviews investigating the benefits of art-based practices for mental-health recovery have stated psychological recovery to be most strongly supported by the constructs of self-discovery and self-expression (Van Lith, Scholfield, \& Fenner, 2012). This parallels the findings from another study that revealed the healing mechanisms of art therapy to be self-exploration, self-expression, communication, understanding and explanation, integration, symbolic thinking, creativity, and sensory stimulation (Blomdahl, Gunnarsson, Guregard, \& Björklund, 2013; Geue et al., 2010).

The essence of experiencing the creative process as a spiritual practice carries the capacity to heal by allowing one to get in touch with the real nature of the self and the beauty and mystery of life (Sutherland, 1995). Thus, creativity and transformation become interrelated in every context or act of art creation (Cajete, 2000). Franklin (2001) emphasized artistic activity to be strikingly similar to the process of selfrealization, which is known as Samadhi in the Yogic culture, and to allow one to nurture a personal reality. This becomes possible through self-immersion, diving into the present and losing track of time, eliminating the duality of the object and subject of art, forming deliberate action, and focusing and increasing attention. Moon (2001) suggested art making to be an alternative language of prayer language and considered prayer as spiritual connectedness having a social nature and communicative function. She interpreted art as a prayer that includes a claim to understanding the dormant parts of the self, may be strong, fragile, broken, frightening, fearful, or brave. In other words, art is the desire to extend expression to the unknown. In this way, instead of praying passively, one actively expresses pain, creates hope, and recreates the self. Practicing art thus enables personal exploration and growth (Allen, 1995; Cameron \& Bryan, 1992; Moon, 2002). 
In a longitudinal multiple-case study, participants reported that they saw art making to be directly related to spirituality and that they had rebuilt a sense of self and a renewed perspective through art making over a one-year period (Van Lith, 2014). In another study investigating the contribution of art to spirituality in addiction recovery, Chickerneo (1990) reported the participants to have experienced admissions of powerlessness, identification, knowledge, and self-acceptance. Conway's study (1999), which was designed as an art therapy program utilizing twelve steps and Rogerian principles, found art therapy effective at fostering increased selfawareness, self-esteem, empowerment, and spiritual development. In one case study, a childhood sexual-trauma survivor was reported realizing a spiritual life that she had not considered possible prior to the art therapy experience. In other words, she had realized and awakened her spiritual aspect, which had previously been dormant (Margolis, 2004). Considering that facing inner realities and meeting one's true self is not always easy, the pleasurable aspect of art making makes the negative content tolerable and helps one cope with the negative emotions and experiences that come out during the art-making process (Czamanski-Cohen \& Weihs, 2016).

\section{Transcendence}

The creative process is one of the main elements of art and has been proposed to provide philosophical evidence of the existence of the transcendent within a person (Franklin, 1999; Grey, 1990). In other words, the inner element that differs from the ego and contains the transcendent essence is revealed through the process of creation. This becomes possible by transcending the linear explanations of known reality and direct self-experience (Malchiodi, 2005; Turner, 2005). Transpersonal events thus allow participants to discover humility and conscientiousness, which leads to a more robust and holistic sense of understanding their life (Ridgway, 2001).

Creating art work can also be understood as a process of creation in the microcosmos (Franklin, 2001). Allen (1995) stated that many artists consider the Supreme as the source of artistic images and Soul as the state of flow. This is similar to the indigenous understanding, which sees art "as a form of individual expression that speaks the language of the soul and connects the individual to their inner sources of life" (Cajete, 1994, p. 30). On the other hand, human beings' being created in the image of God, a belief that exists in the monotheistic tradition, is explained as the partnership of men and women's willingness and ability to do things with God. Being created in the image of God, humans are gifted with the ability to create, and artistic work is akin to co-creating with God. Engaging in creation in the artistic sense means surrendering to the supreme (Sayers, 1941), which cannot be grasped by the senses and wisdom but by imagination, which is an instrument of faith (Moon, 2001; Tenik, 2014). 
Art is a kind of meditation. The person experiences some sense of relief while making art; not through experiencing catharsis or gaining insight but through a strong experience of focusing on something completely outside of the self (Farrelly-Hansen, 2001). Physicist and expressive art therapist Paulo Knill (2000, p.7) described the experience of art making as "the practice of leaving the everyday situation and entering into a devotional space for a period of time." Being engaged in art making is also similar to praying in that it evokes a great sense of wonder and a transcendental reality beyond the self(Moon, 2001). Joy Schaverien (1987) compared the experience of art therapy to a kind of ritual transference. First, one reflects one's attitudes and status to the object of the art; this object acts as a kind of talisman. The second stage has a kind of ritual relief and salvation regarding the existing situation by dissolving in the face of this object.

Kossak (2009) pointed to the attunement phenomena as a transpersonal experience seen in the art making process. He defined it as "being one with another being." He stated this "experience of unitive" to be comparable to Maslow's (1964) peak experiences, which are "sensory or perceptual experiences that are typically shortlived, yet profound, and are accompanied by a sense of enhanced perception, appreciation, or understanding" (Kossak, 2009, p. 14). Marek (2001) pointed out the same phenomena, stating that people who come to art therapy forget everything when they face colorful paints at the beginning of the process and experience some kind of daze. Becoming absorbed by colors, shapes, and images may enable clients to better relate to their own nature and to experience a kind of meditation. Marek stated that this experience, in which the perceiver and the perceived are one, has the power of healing. Similarly, Sutherland (1995) indicated that words distinguish between states of being and experiencing. However, practicing an art form unifies the experience and the end result this experience created.

In one study on spiritually-oriented art therapy, participants reported feeling as if God had communicated with them, feeling a state of clarity through the making and/ or processing of art, and also having knowledge of God and self (Chickerneo, 1990). Another study, this one a case study, revealed that the participant had experienced "a transpersonal connection to the numinous, where she achieved freedom from her shadow and gained the ability to see beyond herself as a traumatized child and into the cosmos" (Margolis, 2004, p. 79). Johnson (2013), with her study incorporating indigenous search methods, reported entering into "a profound deep unknowing and an intense sense of wonder that disrupted and disarmed the controlling nature of the rational mind," consciousness of another world (i.e., altered state of consciousness), journeying into the inner realm of meaning, moments of bliss, spiritual joy, and flow. She explained her experience as "My mind opened to the consciousness of creation 
and I experienced a re-spiriting of the 'more than human world.' It was not an 'other worldly' experience, but rather the experience of 'simultaneous realities.'"

\section{Search for a Purpose and Meaning Making}

Victor Frankl (1984) indicated the search for meaning as the primary motivation in humankind and emphasized the will to find meaning over mere gratification. In particular, people with serious diseases were observed asking "big questions," inquiring about the meaning and purpose of life and having an increased spiritual awareness (Simonton \& Sherman, 1998; Ferrell \& Coyle, 2008). Cicely Saunders (1978) created the concept of total pain for expressing the close relationship of physical, emotional, social, and spiritual pain in an integrated way and the importance of taking care of the overall pain holistically. Illness is something experienced not only in the physical realm but also in the realms of the soul, spirit, and society (Kliewer \& Saultz, 2006). Pain and suffering in the psychological sense are considered as different entities, and their relation is explained as "Pain that persists without meaning becomes suffering" (Ferrell \& Coyle, 2008), which implies the importance of holistic understanding. However, recovery research has been criticized for tending to overlook the extent of the process of finding meaning and purpose (Van Lith, 2014).

Spirituality is described as "the way individuals seek and express meaning and purpose, and the way they experience their connectedness to the moment, to self, to others, to nature, and to the significant or sacred" (Puchalski, 2012, p. 64). Art is basically a means for knowing the self, and knowing oneself through imagery in one's own art is a spiritual path (Allen, 1995). When considering the subjectivesymbolic nature of art and its strength in exploring, identifying, and sharing one's innermost spiritual beliefs, art is an effective way for meaning making (Krippner, 1998). People may experience things that challenge prior understandings of the world and their place in it, and arts-based enquiries help with representing and reflecting upon those experiences and thus facilitate meaning-making. This makes arts-based enquiries a natural ally of spiritual growth and care (McNiff, 2004; Stanworth, 2003).

Studies show participation in art-making to be directly related to developing a sense of purpose (Secker, Spandler, Hacking, Kent, \& Shenton, 2007). In another study, participants reported making art to develop, reinforce, and/or re-establish their existential constructions of values and beliefs. It provides a concrete task for questioning the reason for existence and enables new understandings about the meaning of life (Van Lith, 2014). In another study, one of the themes that emerged as a result of the group art-making process over six sessions was found to be identifying personal meanings within the elements of art (Chickerneo, 1990). 


\section{Reaching Integrity Through Holistic Wellbeing Approach}

Art therapy is a holistic therapeutic approach that aims to enable people who are in fragmented states to achieve integrity, unity, harmony, and balance by taking into account all the mental, emotional, physical, and spiritual dimensions of human nature (Doyle, 2001). An important detail to remember seems to be the meaning of the word healing, which comes from the root haelen and means being a whole or making whole (Heal, 2019).

Healing is a natural element, but it can only be realized by adapting to natural rhythms, especially in today's world in which we may feel disconnected from the rhythms of the earth in everyday life. Adapting to natural rhythms is only possible by knowing who one is and experiencing integrity and completeness (Marek, 2001). Intellect and intuition are two important sources of information (Ornstein, 1972). While art-making is related to intuition, evaluation and integration are related to logic/cognition. Adler (1914, as cited in Ackernecht, 1988) also emphasized the existence of artistic and creative vision and the internal knowledge that comes with intuition as sources of information. Art making stimulates the creative processes that are blocked by the sense of inferiority logical processes create; it revives and repairs the soul by giving shape to life experiences (McNiff, 1992).

In the lifestyle of today's Western world, the intuition part seems to have been forgotten. Arts and humanities emphasize that multiple ways of knowing exist and encourage us to value them all, particularly experiential and presentational knowing (Hartley, 2012). However, Earley's (2002) study of the social evolution of consciousness over five eras of human history showed an ever increasing distancing in the evolution of Western consciousness from participatory consciousness in favor of a reflexive consciousness. Ermine (1995, p. 111), explaining Aboriginal epistemology, stated the fragmentary self-world view permeating the Western world to be seen as detrimental and criticized Western education for "promoting the dogma of fragmentation and indelibly harming the capacity of holism." This understanding stresses the linkage between all aspects of a person and the artificiality of separating them. Basically, if something physically happens to a person, its affects are also social, spiritual, and relational (Kliewer \& Saultz, 2006).

According to the holistic wellbeing approach, a person in essence carries health and wellbeing, and art enables one to come into contact with inner health and wellbeing to achieve integrity. This approach does not attempt to repair the person. It points out that cure and healing belong to a transpersonal and spiritual context rather than a clinical one. It emphasizes that its target is not those who are ill but those who are unaware of their heart, senses, creativity, spontaneity, festivity, and connection with the world and the cosmos (Marek, 2001). The symptoms of psychological 
disorders can be characterized as the voice of the soul, and caring for the soul by imagining is necessary on this point; furthermore (Moore, 1992), art is a good way for this. The World Health Organization's (WHO, 2019) description of health as "a state of complete physical, mental, and social well-being, and not merely the absence of disease or infirmity" also stresses the importance of a holistic perspective.

Art therapy has been found to work holistically through all seven aspects of a person (i.e., psychological, social, clinical, occupational, contextual, spiritual, and self-care; Van Lith, 2014; Van Lith, Schofield, \& Fenner, 2012). Three different models explaining the mechanisms of change induced by art therapy all demonstrate a holistic effect. The Expressive Therapies Continuum (ETC; Lusebrink, 2010) proposed that creative art therapies work on both the kinesthetic/sensory and perceptual/affective levels as well as cognitive/symbolic levels. Sensory/physical experiences are thought to trigger emotional affective and perceptual responses, and in that way make reshaping psychological and decision-making processes possible. The recovery model (Hanevik, Hestad, Lien, Teglbjaerg, \& Danbolt, 2013) has emphasized that art therapy's focus not be on clinical recovery but on holistic health, which tries to provide patients the highest quality of life. Lastly, the bodymind model, which draws on the neuroscientific literature, stresses the perspective of taking the body and mind as a unity rather than seeing them from a Cartesian framework. Its primary premise is that the "processes of mind (thinking and feeling) are embedded in one's sensory and motor experiences" (Czamanski-Cohen \& Weihs, 2016, p. 64). This embodied perspective of cognition and emotion explains art therapy as a developmental, epigenetic, and dynamic process that includes four therapeutic processes: the triangular relationship (between art therapist, art process, and art product), self-engagement, embodied self-expression through the transition from implicit to explicit processing, and meta-cognitive processes.

\section{Conclusion}

Art therapy is a young discipline, and spiritual orientation in art therapy is a more recent effort. Although both quantitative and qualitative studies are being conducted in the field of art therapy with increasing speed, some criticisms have also been expressed about these studies. These criticisms are its lack of methodological rigor; considerable diversity in terms of aim, scope, context, techniques, structures, study design, and measure; the need for standardizing intervention methods; lack of followups; small sample sizes; unclear explanations of how to apply approaches; lack of evidence-based studies; and non-random control groups (Blomdahl, Gunnarsson, Guregard, \& Björklund, 2013; Chiang, Reid-Varley, \& Fan, 2019; Van Lith, 2016). These issues have been reported to make establishing a common theoretical foundation for art-therapy research difficult, and they need to be considered in future studies. 
On the other hand, some art therapists have a skeptical position toward scientific evaluation, claiming it to have a negative evaluation of the creative process (Grulke, Bailer, Stahle, \& Kachele, 2006, as cited in Geue et al., 2010), and standardization may also be an issue considering that pioneers praise spontaneity, flexibility, and artistic rigor (Rubin, 2012).

All in all, art therapy with its unique methods is a promising young discipline. While many more studies are obviously needed for a solid scientific foundation, particularly with regard to spiritually-oriented interventions, including the spiritual dimension in the therapeutic atmosphere is thought to reinforce the holistic approach and to give art therapy the potential to play an important role in the field.

\section{References}

Ahlskog, G. (1990). Atheism and pseudo-atheism in the psychoanalytic paradigm. Psychoanalysis and Contemporary Thought, 13(1), 53-77.

American Art Therapy Association (2017) Definition Art Therapy. Retrieved from https://www. arttherapy.org/upload/2017_DefinitionofProfession.pdf

Allen, P. B. (1995). Art is a way of knowing: A guide to self-knowledge and spiritual fulfilment through creativity. Shambhala Publications.

Allen, P. B. (2013). Intention and witness: tools for mindfulness. In L. Rappaport (Ed), Mindfulness and arts therapies (pp. 51-63). London: Jessica Kingsley

Bell, S. (2011). Art therapy and spirituality. Journal for the Study of Spirituality, 1(2), 215-230.

Blomdahl, C., Gunnarsson, A. B., Guregård, S., \& Björklund, A. (2013). A realist review of art therapy for clients with depression. The Arts in Psychotherapy, 40(3), 322-330.

Cajete, G. (1994). Look to the mountain: An ecology of indigenous education. Kivaki Press, Durango

Cajete, G. (2000). Native science: Natural laws of interdependence. Clear Light Pub.

Cameron, J., \& Bryan, M. (1992). The Artist Way. GP Putnam's Sons, New York.

Chiang, M., Reid-Varley, W. B., \& Fan, X. (2019). Creative art therapy for mental illness. Psychiatry Research, 275, 129-136.

Chickerneo, N. B. (1990). New images, ancient paradigm: A study of the contribution of art to spirituality in addiction recovery (Order No. 9110801). Available from ProQuest Dissertations \& Theses Global. (303993059).

Ciornai, S. (2015). Consciousness Expansion. In The Wiley handbook of art therapy, 47.

Cobb, M. 2001. The Dying Soul: Spiritual Care at the End of Life. Buckingham, UK: Open University Press.

Conway, N. A. (1999). Spiritual transformations: An art therapy program design utilizing twelve step and Rogerian principles (Order No. 1394021). Available from ProQuest Dissertations \& Theses Global. (304579033).

Corrigan, P., McCorkle, B., Schell, B., \& Kidder, K. (2003). Religion and spirituality in the lives of people with serious mental illness. Community Mental Health Journal, 39(6), 487-499. 
Czamanski-Cohen, J., \& Weihs, K. L. (2016). The bodymind model: A platform for studying the mechanisms of change induced by art therapy. The Arts in Psychotherapy, 51, 63-71.

Davidson, L., \& Roe, D. (2007). Recovery from versus recovery in serious mental illness: One strategy for lessening confusion plaguing recovery. Journal of Mental Health, 16(4), 459-470.

Dossey, L. (1997). Notes on the journey: The return of prayer. Alternative Therapies in Health and Medicine, 3(6), 10-17, 113-120.

Doyle, C. (2001). Spirituality and art therapy (Order No. MQ90369). Available from ProQuest Dissertations \& Theses Global. (304721362). Retrieved from https://0-search-proquest-com. seyhan.library.boun.edu.tr/docview/304721362?accountid=9645

Earley, J. (2002). The social evolution of consciousness. Journal of Humanistic Psychology, 42(1), $107-132$

Elkins, J. (1995). Art history and images that are not art. The Art Bulletin, 77(4), 553-571.

Ermine, W. (1995) Aboriginal Epistemology, In M. Battiste (Ed) First nations education in Canada: The circle unfolds. UBC Press Vancouver

Farrelly-Hansen, M. (2001). Spirituality and art therapy: Living the connection. Jessica Kingsley Publishers.

Ferrell, B.R., and Coyle, N. (2008). The nature of suffering and the goals of nursing, Oxford University Press.

Frankl, V. E. (1984). Man's search for meaning, New York: Touchstone.

Franklin, M. (1999) 'Becoming a Student of Oneself: Activating the Witness in Meditation, Art and Supervision.' The American Journal of Art Therapy, 38(1), 2-3.

Franklin, M. (2001). The Yoga of Art and the Creative Process. In M. Farrelly-Hansen (Ed). Spirituality and art therapy: Living the connection. Jessica Kingsley Publishers.

Franklin, M. A. (2015). Essence, Art, and Therapy: A Transpersonal View@. The Wiley handbook of art therapy. Wiley-Blackwell.

Franklin, M., Farrelly-Hansen, M., Marek, B., Swan-Foster, N., \& Wallingford, S. (2011). Transpersonal art therapy education. Art Therapy, 17(2), 101-110.

Geue, K., Goetze, H., Buttstaedt, M., Kleinert, E., Richter, D., \& Singer, S. (2010). An overview of art therapy interventions for cancer patients and the results of research. Complementary Therapies in Medicine, 18(3-4), 160-170.

Grey, A. (1990) Sacred mirrors: The visionary art of Alex Grey. Rochester, VT: Inner Traditions International.

Hanevik, H., Hestad, K. A., Lien, L., Teglbjaerg, H. S., \& Danbolt, L. J. (2013). Expressive art therapy for psychosis: A multiple case study. The Arts in Psychotherapy, 40(3), 312-321.

Hartley, N. (2012). Spirituality and the arts: Discovering what really matters. In M. Cobb, C. M. Puchalski and B. Rumbold (Eds.) Oxford textbook of spirituality and health (pp.265-271). NY: Oxford University Press.

Heal. (2019). In Chambers's Twentieth Century Dictionary. Retrieved from http://www. finedictionary.com/heal.html

Health, 2019. The World Health Organiztion. Retrieved from https://www.who.int/about/who-weare/frequently-asked-questions

Hillman, J. (1975). Revisioning psychology. New York, NY: Harper Colophon. 
Hillman, J. (1977). Inquiry into image. An Annual of Archetypal Psychology and Jungian Thought (pp. 62-88). Zurich: Spring.

Hluska, M. E. (2016). Understanding the roles and uses of art making in art therapy (Order No. 10182396). Available from ProQuest Central; ProQuest Dissertations \& Theses Global. (1845326808).

Horovitz-Darby, E. G. (1994). Spiritual art therapy. Springfield, IL: Charles C Thomas.

Johnson, P. (2013). When the sacred stories are told: Coming to life through creativity, art, and embodied consciousness (Order No. 3567435). Available from ProQuest Dissertations \& Theses Global. (1417764716).

Joko Beck, C. (1989) Everyday Zen. San Francisco: HarperCollins.

Jung, C. G. (1961/2011). The undiscovered self with symbols and the interpretation of dreams. Princeton University Press.

Junge, M. B., \& Asawa, P. P. (1994). A history of art therapy in the United States. American Art Therapy Association.

Junge, M. B., \& Wadeson, H. (Eds.). (2006). Architects of art therapy: Memoirs and life stories. Charles C Thomas Publisher.

Kapitan, L. (2014). Introduction to the neurobiology of art therapy: Evidence based, complex, and influential. Art Therapy, 31:2, 50-51, DOI: 10.1080/07421656.2014.911027

Kearney, M., \& Mount, B.(2000).Spiritual care of the dying patient. In H. M. Chochinov \& W. Breitbart (Eds.) Handbook of psychiatry in palliative medicine (pp.357-373). Oxford, UK: Oxford University Press

Kliewer, S. P., \& Saultz, J. (2006). Healthcare and spirituality. Oxford: Radcliffe Publishing

Knill, P. J. (2000). The essence in a therapeutic process: An alternative experience of worlding. Poiesis. A Journal of the Arts and Communication, 2, 7-14.

Koepfer, S. T. (2000). Drawing on the spirit: Embracing spirituality in pediatrics and pediatric art therapy. Art Therapy, 17(3), 188-194.

Kossak, M. S. (2009). Therapeutic attunement: A transpersonal view of expressive arts therapy. The Arts in Psychotherapy, 36(1), 13-18.

Krippner, S. (1998). Indigenous and postmodern psychologies. In M. Inman (Ed.), Proceedings: Third Annual Alternative Therapies Symposium (pp. 57-59). Aliso Viejo, CA: Innovision Communications.

Kübler-Ross, E. (1983). On children and death. How children and parents can and do cope with death. Touchstone, New York, NY.

Landgarten, H. B. (1981). Clinical art therapy a comprehensive guide. New York: Bruner.

LaPointe, F. M. (2009). The individuation process of a disciple: A study of C. G. Jung and MarieLouise von Franz (Order No. 3500706). Available from ProQuest Dissertations \& Theses Global. (928458214).

Larson, D. B. (1998). Health: What does God have to do with it?. In M. Inman (Ed.), Proceedings: Third Annual Alternative Therapies Symposium (pp. 135-144). Aliso Viejo, CA: Innovision Communications.

Larson, D., Swyers, J., \& McCullough, M. (1997). Scientific research on spirituality and health: a consensus report National Institute for Healthcare Research. Rockville, MD: The John Templeton Foundation.

Malchiodi, C. A. (2003). Handbook of art therapy. Guilford Press. 
Malchiodi, C. A. (2005). Expressive therapies: history, theory, and practice, In C. A. Malchiodi (ed.) Expressive therapies, The Guildford Press, New York, pp. $1-15$.

Malchiodi, C. A. (2006). The art therapy sourcebook. New York: McGraw-Hill Companies.

Marek, B. (2001). Each Time a New Breath. In M. Farrelly-Hansen (Ed). Spirituality and art therapy: Living the connection. Jessica Kingsley Publishers.

Margolis, J. B. (2004). The personal meaning of art therapy for a survivor of childhood sexual abuse (Order No. 3158580). Available from ProQuest Dissertations \& Theses Global. (305098092).

Matthews, D. A., \& Clark, C. (1999). The faith factor: Proof of the healing power of prayer. Penguin.

McNiff, S. (1981). The arts and psychotherapy. Charles C. Thomas Publisher.

McNiff, S. (1992). Art as medicine: Creating a therapy of the imagination. Shambhala Publications.

McNiff, S. (2004). Art heals: How creativity cures the soul. Boston: Shambhala.

Monti, D. A., Peterson, C., Kunkel, E. J. S., Hauck, W. W., Pequignot, E., Rhodes, L., \& Brainard, G. C. (2006). A randomized, controlled trial of mindfulness $\square$ based art therapy (MBAT) for women with cancer. Psycho $\square$ Oncology: Journal of the Psychological, Social and Behavioral Dimensions of Cancer, 15(5), 363-373.

Moon, C. (2001). Prayer, sacraments, grace. In M. Farrelly-Hansen (Ed), Spirituality and art therapy: Living the connection, (pp. 29-51). Jessica Kingsley Publishers.

Moon, C. H. (2002). Studio art therapy: Cultivating the artist identity in the art therapist. London: Jessica Kingsley

Moore, T. (1992). Care of the soul. New York: Harper Perennial.

Olivera, B., Toler, R., \& Trevithick, C. (2001). Factual information about the profession of art therapy. In M. Farrelly-Hansen (Ed), Spirituality and art therapy: Living the connection, (pp. 254-258). Jessica Kingsley Publishers.

Ornstein, R. (1972). The psychology of the unconscious. New York: Prentice Hall Press.

Puchalski, C. M. (2012). Spirituality in the cancer trajectory. Annals of oncology, 23(3), 49-55.

Ridgway, P. (2001). Restorying psychiatric disability: learning from first person recovery narratives. Psychiatric Rehabilitation Journal, 24(4), 335.

Rubin, J. A. (2012). Approaches to art therapy: Theory and technique. Routledge.

Saunders, C. (1978). The philosophy of terminal care. In: C. Saunders (ed.) The Management of Terminal Disease, pp. 193 - 202. London: Edward Arnold.

Schaverien, J. (1987). The scapegoat and talisman: Transference in art therapy. In images of art therapy. Routledge.

Secker, J., Spandler, H., Hacking, S., Kent, L., \& Shenton, J. (2007). Empowerment and arts participation for people with mental health needs. Journal of Public Mental Health, 6(4), 14-23.

Simonton, S. S., \& Sherman, A. C. (1998). Psychological aspects of mind-body medicine: promises and pitfalls from research with cancer patients. Alternative Therapies in Health and Medicine, 4(4), 50-8.

Soden, L. M. (1998). Insight imagery: Towards personal wellness through spontaneous art-making and empathic co-reflection (Order No. NQ35326). Available from ProQuest Dissertations \& Theses Global. (304474578).

Spiritus. (2019). In Chambers's Twentieth Century Dictionary. Retrieved from http://www. finedictionary.com/spirituality.html 
Stanworth, R. (2003). Recognizing Spiritual Needs in People Who are Dying. Oxford: Oxford University Press.

Steiner, R. (1964). The arts and their mission. Anthroposophic Press.

Sutherland, J. H. (1995). A perspective on Adlerian art therapy including a spiritual dimension: An interdisciplinary model for the training of art therapy counsellors based on the constructs of individual psychology (Order No. 9613183). Available from ProQuest Dissertations \& Theses Global. (304288781).

Swinton, J. (2001). Spirituality and mental health care: Rediscovering a 'forgotten' dimension. Jessica Kingsley Publishers.

Tenik, A. (2014). Tasavvufi perspektifte nesnedeki sanat ve estetik algısı. İslam ve Sanat Tartışmalı İlmi Toplant1, Kasım 2014. Retrieved from http://isamveri.org/pdfdrg/D237891/2015_TENIKA. pdf

Tournier, P. (1964). The whole person in a broken world. Harper \& Row, NY.

Turner, B. A. (2005). The handbook of sandplay therapy. Cloverdale, CA: Temenos Press.

Van Lith, T. (2014). "Painting to find my spirit": Art making as the vehicle to find meaning and connection in the mental health recovery process. Journal of Spirituality in Mental Health, 16(1), 19-36.

Van Lith, T. (2016). Art therapy in mental health: A systematic review of approaches and practices. The Arts in Psychotherapy, 47, 9-22.

Van Lith, T., Schofield, M. J., \& Fenner, P. (2013). Identifying the evidence-base for art-based practices and their potential benefit for mental health recovery: a critical review. Disability and Rehabilitation, 35(16), 1309-1323.

Vick, R. M. (2003). A brief history of art therapy. In C. A. Malchody (Ed) Handbook of art therapy, 5-15. The Guilford Press.

Wadeson, H. (1980). Art psychotherapy. New York: John Wiley \& Sons.

Wallace, K. O. (2015). There is no need to talk about this: Poetic inquiry from the art therapy studio (Vol. 106). Springer.

Wix, L. (2000). Looking for what's lost: The artistic roots of art therapy: Mary Huntoon. Art Therapy, 17(3), 168-176.

Yanos, P. T., Roe, D., \& Lysaker, P. H. (2010). The impact of illness identity on recovery from severe mental illness. American Journal of Psychiatric Rehabilitation, 13(2), 73-93. 